
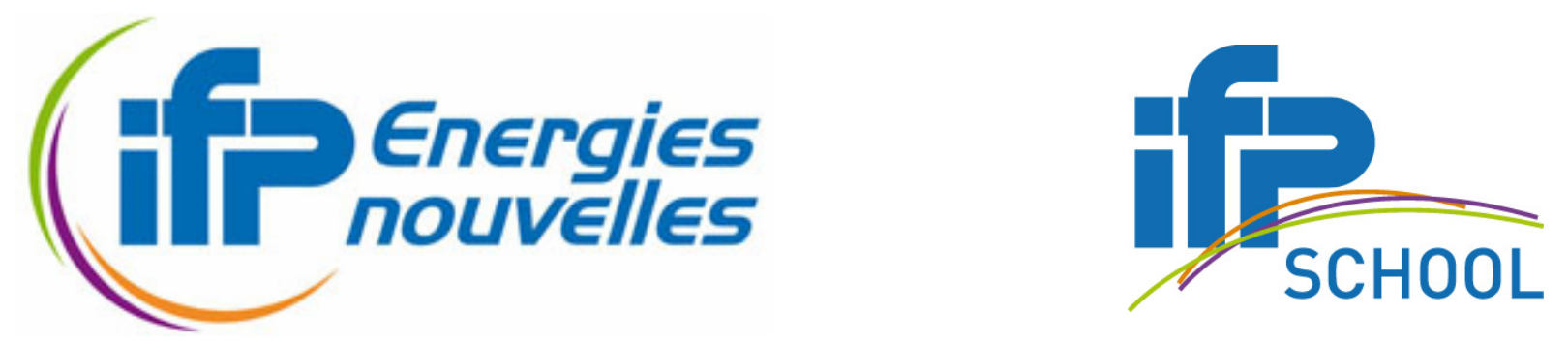

\title{
Does OPEC still exist as a cartel? \\ An empirical investigation.
}

\author{
Vincent BREMOND \\ Emmanuel HACHE \\ Valérie MIGNON
}

Mars 2011

\section{Les cahiers de l'économie - $n^{\circ} 78$}

\section{Série Recherche}

\author{
vincent.bremond@ifpen.fr \\ emmanuel.hache@ifpen.fr \\ valerie.mignon@u-paris10.fr
}

\begin{abstract}
La collection "Les cahiers de l'économie" a pour objectif de présenter des travaux réalisés à IFP Energies nouvelles et à IFP School, travaux de recherche ou notes de synthèse en économie, finance et gestion. La forme peut être encore provisoire, afin de susciter des échanges de points de vue sur les sujets abordés. Les opinions émises dans les textes publiés dans cette collection doivent être considérées comme propres à leurs auteurs et ne reflètent pas nécessairement le point de vue d' IFP Energies nouvelles ou d' IFP School.
\end{abstract}

Pour toute information sur le contenu, prière de contacter directement l'auteur.

Pour toute information complémentaire, prière de contacter le Centre Économie et Gestion: Tél +33 147527227

The views expressed in this paper are those of the authors and do not imply endorsement by the IFP Energies Nouvelles or the IFP School. Neither these institutions nor the authors accept any liability for loss or damage incurred as a result of the use of or reliance on the content of this publication. 



\title{
Does OPEC still exist as a cartel? An empirical investigation
}

\author{
Vincent BREMOND*, Emmanuel HACHE ${ }^{* *}$ and Valérie MIGNON***
}

November 2010

\begin{abstract}
The aim of this paper is to determine if OPEC acts as a cartel by testing whether the production decisions of the different countries are coordinated and if they have an influence on oil prices. Relying on cointegration and causality tests in both time series and panel settings, our findings show that the OPEC influence has evolved through time, following the changes in the oil pricing system. While the influence of OPEC is found to be important just after the counter-oil shock, our results show that OPEC is price taker on the majority of the considered sub-periods. Finally, by dividing OPEC between savers and spenders, we show that it acts as a cartel mainly with a subgroup of its members.
\end{abstract}

JEL Classification: C22, C23, L11, Q40.

Keywords: Oil prices, oil production, OPEC, cartel, cointegration, causality.

\footnotetext{
- Corresponding author: Valérie Mignon, EconomiX-CNRS, University of Paris Ouest, 200 avenue de la République, 92001 Nanterre Cedex, France. Tel. 331409758 60. Fax: 3314409777 84. Email: valerie.mignon@u-paris10.fr.

* EconomiX-CNRS, University of Paris Ouest, and IFP Énergies Nouvelles, 1 et 4 avenue de Bois Préau, 92852 Rueil Malmaison, France. Email: vincent.bremond@ifpenergiesnouvelles.fr.

** IFP Énergies Nouvelles, 1 et 4 avenue de Bois Préau, 92852 Rueil Malmaison, France. Email: emmanuel.hache@ifpenergiesnouvelles.fr.

${ }^{* * *}$ EconomiX-CNRS, University of Paris Ouest, and CEPII, Paris, France. Email: valerie.mignon@u-paris10.fr.
} 


\section{Introduction}

Since the creation of the Organization of the Petroleum Exporting Countries ${ }^{1}$ (OPEC) at the beginning of the 1960s, many authors have focused on its role in the oil market and, notably, its capability to influence oil prices in both the short and long run (see Dahl and Yücel (1989) among others). At the same time, the oil pricing system witnessed major transformations in the last 50 years, which can be summarized by a shift from an administered pricing system to a market related price since the middle of the 1980s. The posted price period, with the different pricing systems in the physical market Gulf price (Single Basis System), was implemented by the International Oil Companies (IOC) at the beginning of the $20^{\text {th }}$ Century. According to Yergin (1991) and Fattouh (2006), the aim of this pricing regime was to lower the tax paid by the IOC to the host countries, leading to a very low and stable official price whatever the market conditions. The entry into the market of new large scale players, such as the Soviet Union at the end of the 1950s, triggered a major change with a huge surplus of production. In reaction, the so-called seven sisters cartel decided to cut by 10 per cent the posted prices in the market to safeguard their market share. This factor can be considered as the key element which triggered the creation of the OPEC in 1960. Nevertheless, it took 13 years for the Organization to claim its "market power" in the oil sector. Since 1973, the oil market as well as the oil pricing regime have thus experienced a period of continuous change.

Within this context, our aim is to investigate the dynamics of the production behavior of countries belonging to the OPEC, as well as non-member countries that are considered as major key players in the oil market. More specifically, our aim is to determine if OPEC acts as a cartel by testing whether the production decisions of the different countries are coordinated and if they have an influence on oil prices.

A related question has been previously investigated by Dahl and Yücel (1989) who test numerous theories about the OPEC behavior. They show that OPEC is not a cartel, and that some countries behave in a non-competitive way or with a target revenue goal. Considering various sub-periods, Loderer (1985) shows that while the announcements of OPEC decisions do not affect prices in the 1974-1980 period, the alternative hypothesis that OPEC could act as a cartel is not rejected during the beginning of the 1980s. Using cointegration and Granger

\footnotetext{
${ }^{1}$ OPEC was formed by five countries (Iran, Iraq, Kuwait, Saudi Arabia, and Venezuela) in September 1960 in Baghdad.
} 
causality tests, Gülen (1996) obtains similar findings: OPEC production Granger-causes oil prices during the 1982-1993 period, whereas none causality is found for the previous periods investigated. Testing different models (namely cartel models, competitive models, target revenue models and property rights models), Griffin (1985) puts forward that the partial market sharing is the best fitted model for the OPEC countries, while non-OPEC countries are better represented by the competitive model. Other studies consider that OPEC is a divided cartel. Hnyilicza and Pindyck (1976) split OPEC in two groups, namely "saver" and "spender" countries, the spender countries being composed of members with an immediate need for cash and rate of discount lower than the savers, and focuses on the bargaining power between these two groups. Following the same typology, Aperjis (1982) concludes that a conflict can exist between OPEC members regarding their production decisions. There also exists a set of studies concerned with target behavior models, such as Teece (1982) and Adelman (1982) who modeled OPEC behavior according to a target revenue model. Alhajji and Huetnner (2000) conclude as well that OPEC does not act as a cartel, and that the target revenue model is not rejected for Algeria, Libya and Nigeria. Finally, one can mention the works by Johany (1980) focusing on the impact of the uncertainty about property rights, and MacAvoy (1982) showing that political events and market fundamentals (a growing demand and speculation) have played a key role in explaining the price dynamics during the 1970s, more than the OPEC behavior itself.

This brief survey of the literature shows that no consensus exists regarding the OPEC production behavior. Our aim is to contribute to this literature by testing if OPEC acts as a cartel. To this end, we rely on time series and panel (i) cointegration techniques to investigate the existence of a long-term relationship between the production of each member and that of the OPEC, and (ii) Granger causality tests to apprehend the influence of OPEC production decisions on oil prices.

The rest of the paper is organized as follows. In Section 2, we briefly describe the major changes observed in the oil pricing regime since the first oil shock, which also define the subperiods of our empirical study. Section 3 describes the data, and Section 4 provides the results of cointegration and causality tests. Finally, Section 5 concludes the article. 


\section{Main changes in the oil pricing regime}

In 1973, the oil market experienced a new way of pricing with the introduction of the Government Selling Price (GSP) or Official Selling Price (OSP). This price can be considered as the historical counter-part of the Posted price implemented by the IOC few decades earlier except that the prices were now determined by OPEC, with the Arabian Light $\left(34^{\circ}, \mathrm{API}\right)$ as the crude marker. OPEC was at that time the dominant player in the market (with more than 50 per cent of the market share).

Nevertheless, if this period was marked by the two world oil shocks (1973-1974 and 19791980), with a sharp increase of the prices on the market-from 3.65 to 11.65 US dollars per barrel between October and December 1973 in nominal terms, and from around 14.00 US dollars in 1978 to 40.85 in November 1980-it also had a significant positive impact on the level of production from countries outside the Organization. Thus, during the 1973-1982 period, the non-OPEC countries' production registered an increase about 44.5 per cent, with Mexico (+ 2.5 millions barrel per day), the United Kingdom (+ 2.0 millions) and Norway (+ 0.5 million) representing around 45 per cent of this increase. It helps to develop the spot markets and can explain the emergence of a dual system in terms of pricing with the coexistence of an OPEC reference price (administered price) and a market price.

This leads to the second sub-period of our study. The 1982-1986 period is characterized by an important decline of oil prices, given rise to the oil counter-shock in 1986 with oil prices at less than 10 US dollars per barrel. It has also conducted to the implementation of the quotas policy by the Organization in March 1982. From 1982 to 1986, the oil pricing system has experienced a transition period with the administered OPEC price which lasts until 1985, a growing influence of the price in the spot markets and the introduction of the netback pricing system in 1986. This latter has been abandoned a few months after due to the implementation of a new market share policy from Saudi Arabia. The year 1986 can be considered as a milestone in the oil markets with the introduction and the widespread of a new system: the market related regime. It represents the first construction phase of a complex structure on the market with the introduction of a pricing system based on three reference prices: West Texas Intermediate (WTI) for North America, Brent for Europe and South American countries, and Oman-Dubai for crude oil sent to the East Asia, by the national Mexican company PEMEX. It also represents a sort of "golden youth" on the oil market including the import of the classical tools of modern finance (swap, options) created by the financial revolution, the so-called “financial big bang" of the early 1980s. During 1986-1993, we observed a sharp increase of 
the liquidity (in terms of financial contracts such as Light Sweet Crude Oil) in the financial market, especially on the New York Mercantile Exchange (NYMEX) and on the International Petroleum Exchange ${ }^{2}$ (IPE). This was followed by a gradual financialization on the market during 1993-2001. For example, the number of futures contract in the NYMEX increased by more than 40 per cent during this period and at the same time the oil-pricing regime experienced some controversy: squeeze, decrease of the liquidity due to a marked decrease of the Brent and WTI production which have introduced some doubts regarding the efficiency of the price formation on the market.

After the introduction at the end of December 2000 of the law modernizing raw materials markets-the Commodity Futures Modernization $\mathrm{Act}^{3}$ (CFMA)—two major changes have been registered. From January 2001 to January 2009, we observed a sharp rise in transaction volumes in the financial markets, and a context of high volatility on the oil market. Between January and July 2008, oil prices increased to almost 147 US dollars per barrel and collapsed a few weeks later to under 35 US dollars per barrel. This context has left many analysts and researchers puzzled by the underlying explanations for determination of prices and the influence of the non-commercial players in the market. The interaction between a physical price based on geographical reference prices and a financial one based on futures contracts with the underlying assumption of a growing speculation factor seems to have changed drastically the market conditions.

This brief description of the main changes in the oil pricing system leads us to consider five sub-periods in our empirical analysis: January 1973 to February 1982, March 1982 to April 1986, May 1986 to February 1993, March 1993 to December 2000, and the period starting in January 2001.

\section{Data and unit root tests}

We consider a sample of 15 countries including (i) 11 countries belonging to the OPEC (Algeria, Indonesia, Iran, Iraq, Kuwait, Libya, Nigeria, Qatar, Saudi Arabia, the United Arab Emirates, and Venezuela), and (ii) 4 other non-OPEC countries (namely Mexico, Norway, the United Kingdom, and Russia). Production and price series are extracted from Datastream.

\footnotetext{
${ }^{2}$ The IPE became the InterContinental Exchange (ICE) in 2001.

${ }^{3}$ For more information, see the CFTC website at http://www .cftc.gov/lawandregulation/index.htm.
} 
We use monthly data from January 1973 to July 2009. Note that for some countries, production data are not available on the whole period. More specifically, we consider Indonesian production until May 2008, given that Indonesia leaves OPEC after that date. For Mexico, Norway and UK, the analysis begins in 1982-due to the establishment of a larger oil production policy than previously-while the Russian analysis starts after its creation in 1991. Furthermore, we exclude Ecuador and Gabon from the analysis because of their coming and going into the Organization.

Recall that our aim is to test for a cooperative behavior between OPEC members by investigating the link between the production of one member country and the global production of the other OPEC members. For each country $i$, we define the production of the other member countries-which we call "rest of the cartel production"-as the difference between the total OPEC production and the individual production of country $i{ }^{4}$

The crude oil price is the UK Brent in US dollars. It is expressed in real terms using the US CPI (extracted from Datastream) as the deflator. Finally, note that production and price series are expressed in logarithmic terms.

The first step is to determine the integration order of our series. Given that our sample period is characterized by various oil pricing regimes (see Section 2), we consider a test robust to structural breaks. We rely on the Zivot and Andrews (1992) test. Under the null hypothesis, there is a unit root without any exogenous structural break, whereas the alternative hypothesis is the stationarity with a break date determined endogenously. The conclusions of the test are reported in Table A1 in the appendix and show that the majority of the considered series are I(1). Table 1 summarizes the results and lists the countries for which both the individual production and the rest of the cartel production are I(1).

\footnotetext{
${ }^{4}$ Note that in the appendix, the rest of cartel prod is denoted as "country2".
} 
Table 1. Individual and rest of the cartel productions integrated of order 1.

\begin{tabular}{|c|c|c|c|c|}
\hline $1973.01-1982.02$ & 1982.03-1986.04 & 1986.05-1993.02 & 1993.03-2000.12 & $2001.01-2009.07$ \\
\hline $\begin{array}{l}\text { Algeria, Indonesia, } \\
\text { Iran, Kuwait, } \\
\text { Libya, Nigeria, } \\
\text { Qatar, Saudi } \\
\text { Arabia, Venezuela. }\end{array}$ & $\begin{array}{l}\text { Algeria, Indonesia, } \\
\text { Iraq, Kuwait, } \\
\text { Qatar, Venezuela, } \\
\text { Mexico, U.K. }\end{array}$ & $\begin{array}{l}\text { Algeria, Indonesia, } \\
\text { Libya, Nigeria, } \\
\text { Qatar, U.K. }\end{array}$ & $\begin{array}{c}\text { Algeria, Indonesia, } \\
\text { Iraq, Libya, } \\
\text { Nigeria, Qatar, } \\
\text { Saudi Arabia, } \\
\text { U.A.E., Mexico, } \\
\text { Norway, U.K., } \\
\text { Russia }\end{array}$ & $\begin{array}{l}\text { Indonesia, Iran, } \\
\text { Iraq, Kuwait, } \\
\text { Libya, Nigeria, } \\
\text { Qatar, Saudi } \\
\text { Arabia, U.A.E., } \\
\text { Venezuela, } \\
\text { Mexico, Norway, } \\
\text { U.K., Russia }\end{array}$ \\
\hline
\end{tabular}

\section{Cointegration and Granger causality tests}

\subsection{Time series analysis}

In order to test for the existence of a long-run relationship between the production of exporting countries and that of the OPEC, we rely on the Engle and Granger (1987) test based on the null hypothesis of no cointegration.

Table 2. Results of the Engle-Granger cointegration test.

\begin{tabular}{ll}
\hline Sub-periods & Cointegrated countries \\
\hline $1973.01-1982.02$ & Algeria, Kuwait, Nigeria, Qatar \\
$1982.02-1986.04$ & Algeria, Indonesia, Mexico \\
$1986.05-1993.02$ & Indonesia, Libya, Nigeria, Qatar \\
$1993.03-2000.12$ & Nigeria, Qatar, U.A.E., Saudi Arabia, Mexico, Norway \\
$2001.01-2009.07$ & Iran, Nigeria, Qatar, Saudi Arabia*, U.A.E.*
\end{tabular}

*: rejection of the null hypothesis of no cointegration at the $10 \%$ significance level. Otherwise, the significance level is $5 \%$.

Results displayed in Table $2^{5}$ show that, for the first three periods, none of the large producing countries is cointegrated with the rest of the Organization production. This result indicates that the individual shares of production are not constant over time. Countries for which cointegration is obtained do not account for more than 30 percent of the OPEC production. Contrary to the first three periods, the 1993.03-2000.12 sample is characterized by the presence of massive producers (particularly Saudi Arabia) accounting for nearly 50 per cent of the OPEC market share. Moreover, the absence of cointegration is also rejected for two

\footnotetext{
${ }^{5}$ See Table A2 in the appendix for the detailed results.
} 
countries belonging to our non-OPEC group, leading to the question of a possible larger agreement between producer countries. This sub-period could also be considered as some kind of "Golden Age" in terms of coordination within the Organization. Finally, in the last period (2001.01-2009.07), cointegration is observed for countries representing about 65 to 70 percent of the OPEC production, but without any non-OPEC producers. As for the previous period, Saudi Arabia belongs to these cointegrated countries.

It is worth noting that during the first three periods characterized by the absence of cointegration for the major oil producers, the OPEC market share in world oil production was highly volatile and unstable (see Figure 1). On the contrary, this market share is quite stable since 1993. These findings may lead us to the conclusion that OPEC also fits its production policy according to the non-OPEC supply and demand.

Figure 1. OPEC market share in world oil production.

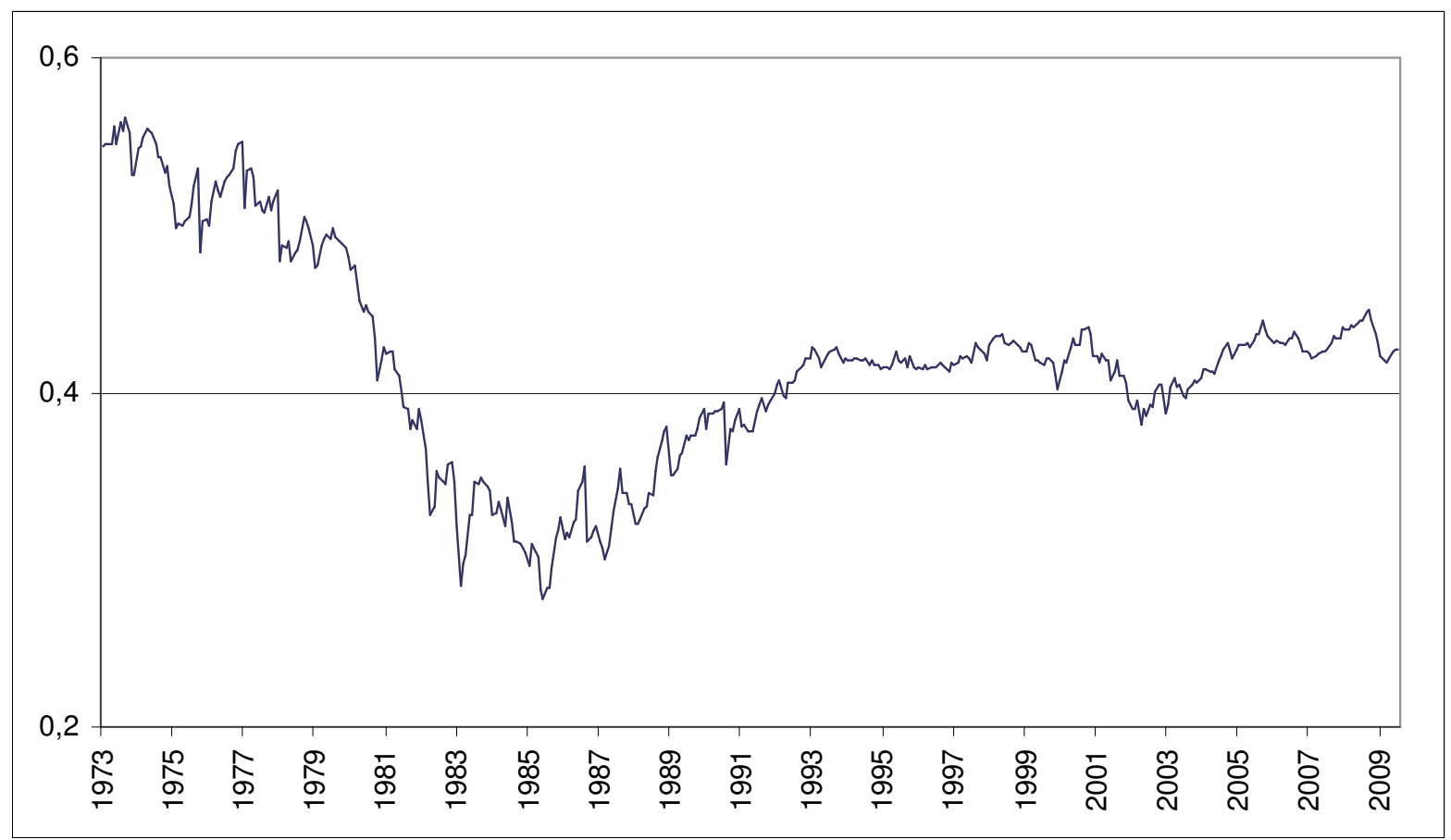

To investigate the direction of the link between production and price series, we implement the Granger causality test. 
Table 3. Results of the Granger causality test.

\begin{tabular}{c|c|c|c|c|c}
\hline & $1973.01-$ & $1982.03-$ & $1986.05-$ & $1993.03-$ & $2001.01-$ \\
1982.02 & 1986.04 & 1993.02 & 2000.12 & 2009.07 \\
\hline Price-Prod & Libya & $\begin{array}{c}\text { Venezuela, } \\
\text { Mexico, Qatar, } \\
\text { OPEC* }\end{array}$ & S. Arabia & $\begin{array}{c}\text { UAE, Mexico, } \\
\text { OPEC }\end{array}$ & $\begin{array}{c}\text { Iran, Kuwait, } \\
\text { Libya, S. } \\
\text { Arabia, UAE, } \\
\text { UK, Russia, } \\
\text { OPEC }\end{array}$ \\
\hline Prod-Price & - & Algeria, Iraq* & $\begin{array}{c}\text { Libya, Qatar, } \\
\text { Algeria, } \\
\text { Nigeria, } \\
\text { OPEC*, S. } \\
\text { Arabia* }\end{array}$ & UAE & Venezuela* \\
& & & & & \\
\hline
\end{tabular}

*: rejection of the null hypothesis of no causality at the $10 \%$ significance level. Otherwise, the significance level is $5 \%$. Price-prod: null of no causality from price to production, prod-price: null of no causality from production to price.

The first main conclusion that emerges from Table $3^{6}$ is that, except for Libya, we can not reject the null hypothesis of no causality for each OPEC member during the first controversial 1973.01-1982.02 sub-period (including two oil shocks). As a consequence, there is no evidence that production policies are linked to price movements, a result which is relevant with the fact that the price was fixed during this period. The second sub-period is mainly characterized by the rejection of the null hypothesis of no causality from price to production for the OPEC as a whole, illustrating the fact that OPEC is price taker. Whereas the links between price and production are relatively weak in this period, the null of no causality from production to price is rejected for major producers in the third period, with a feedback effect observed for Saudi Arabia. The sub-period following the counter shock is thus the only one for which the OPEC production policy seems to have had an effect on price. It reflects the abandonment of the "netback" pricing system from Saudi Arabia and other OPEC countries which experienced the former system. For the fourth period, the main finding is the existence of a relation running from price to production for the OPEC. The last period is probably one of the most interesting, because several producers display a link from price to production in a context of increasing prices. Once again, OPEC is price taker. The characteristics of these countries are interesting as well. Actually, if we consider Saudi Arabia, U.A.E., Kuwait, Libya and Iran, we can notice that, according to BP 2009 Statistical Review, these countries have some of the largest Reserves/Production (R/P) ratios (see also Table 4).

\footnotetext{
${ }^{6}$ Detailed results are reported in Table A3 in the appendix.
} 
These results lead us to test if there is a split between countries inside OPEC itself. We classify the member countries into two sub-groups:

- “saver” group: Iran, Libya, Kuwait, Qatar, Saudi Arabia, U.A.E. and Venezuela;

- “spender" group: Algeria, Indonesia, Iraq and Nigeria.

This separation aims at investigating if some countries have more incentive to cheat than others. To explain this behavior, suppose that cheating is induced by the short-run wish to earn money. Various reasons may justify this behavior. The first one relies on demographic facts: a country with a large population and/or an increasing growth rate will have to "feed" its population. Second, the type of crude oil may play an important role. It seems reasonable to think that good quality crude (i.e. with the lightest and lowest sulfur content) will be easily sold (and at a higher price), whatever the price. Thus, the owner has a relative less incentive to let oil in the ground, which involves faster reserves depletion. Finally, the type of political regime matters. A democratic regime supposes regular election dates and so, a short or midterm view. Given that the population opinion obviously plays a crucial role in winning votes and elections, accounting for it may justify the "spending oil" behavior of countries to earn money.

Table 4 reports some descriptive characteristics for our two groups of countries. The spender group is characterized by large population countries (from 28 to 240 millions), with a very valuable crude oil (but with small reserves), and a (relatively) flexible political regime. Note that the presence of Iraq is due to three major wars, which involves that political regimes have to rebuild the country. The saver group — characterized by a smaller discount rate than the spenders-is composed by small population countries (between 830000 and 66 millions), with large R/P ratios, and relatively heavier crude oil. These countries are less democratic than the other ones; the two exceptions being Iran and Venezuela due to their specific political regimes. Furthermore, despite a low R/P ratio, Qatar is included too because of its high gas reserves, making oil business only as a complement into the Qatari GDP. Let us now investigate the specific properties of these two groups of countries through a panel data analysis. 
Table 4. Descriptive facts.

\begin{tabular}{|c|c|c|c|c|c|c|c|c|}
\hline Countries & $\begin{array}{l}\text { Population (in } \\
\text { millions) (CIA } \\
\text { Factbook) }\end{array}$ & $\begin{array}{l}\text { Pop. Growth Rate } \\
\text { (CIA Factbook) }\end{array}$ & $\begin{array}{c}\text { Rate of } \\
\text { Unemployment } \\
\text { (CIA Factbook) }\end{array}$ & $\begin{array}{l}\mathrm{R} / \mathrm{P}(\mathrm{BP} \\
\text { Stats) }\end{array}$ & $(\mathrm{R} / \mathrm{P}) / \mathrm{pop}$ & $\begin{array}{l}\text { Current Balance } \\
\text { (2008 \& 2009) (in } \\
\$ \text { billion) }\end{array}$ & $\begin{array}{c}\text { Type of Crude (Heaviness, Sulfur } \\
\text { Content) (Energy Intelligence } \\
\text { Group) }\end{array}$ & $\begin{array}{l}\text { Type of politica } \\
\text { regime (CIA } \\
\text { Factbook) }\end{array}$ \\
\hline Algeria & 34.18 & 1.196 & $10.2 \%$ & 16.7 & 0.48 & $(34.45 \&-4.26)$ & Light, Low Sulfur Content & Republic \\
\hline Indonesia & 240.27 & 1.136 & $7.7 \%$ & 10.2 & 0.004 & $(0.125 \& 10.58)$ & Light, Low Sulfur Content & Republic \\
\hline Iraq & 28.95 & 2.506 & $15.2 \%$ & (a) & $>3.45^{*}$ & $(12.2 \&-19.9)$ & $\begin{array}{l}\text { Medium, Low to medium sulfur } \\
\text { Content }\end{array}$ & $\begin{array}{l}\text { Republic } \\
\text { (instable) }\end{array}$ \\
\hline Nigeria & 149.23 & 2 & $5 \%$ & 45.6 & 0.31 & $(39.36 \& 10.01)$ & Medium, Low Sulfur Content & $\begin{array}{l}\text { Federal } \\
\text { Republic }\end{array}$ \\
\hline Iran & 66.43 & 0.883 & $11.8 \%$ & 86.9 & 1.30 & $(23.99 \& 2.653)$ & $\begin{array}{l}\text { Medium, Medium to high sulfur } \\
\text { content }\end{array}$ & $\begin{array}{l}\text { Islamic } \\
\text { Republic }\end{array}$ \\
\hline Kuwait & 2.69 & 3.549 (b) & $2.2 \%$ & 99.6 & 37.03 & $(64.78 \& 32.01)$ & Medium, High Sulfur Content & $\begin{array}{l}\text { Constitutional } \\
\text { Emirate }\end{array}$ \\
\hline Libya & 6.32 & 2.172 & $30 \%$ & 64.6 & 10.2 & $(35.7 \& 8.257)$ & $\begin{array}{l}\text { Medium, Low to medium Sulfur } \\
\text { Content }\end{array}$ & $\begin{array}{l}\text { Authoritarian } \\
\text { state, de facto }\end{array}$ \\
\hline Qatar & 0.83 & 0.957 & $0.5 \%$ & 54.1 & 65.18 & $(14.23 \& 4.619)$ & $\begin{array}{l}\text { Low to High, Medium Sulfur } \\
\text { Content }\end{array}$ & Emirate \\
\hline Saudi Arabia & 28.69 & 1.848 & $11.7 \%$ & 66.5 & 2.318 & $(133.5 \& 26.5)$ & Medium, Medium sulfur Content & Monarchy \\
\hline U.A.E. & 4.80 & 3.689 & $2.4 \%$ & 89.7 & 18.68 & $(22.31 \&-4.04)$ & $\begin{array}{l}\text { Medium, Low to Medium Sulfur } \\
\text { Content }\end{array}$ & $\begin{array}{l}\text { Federation of } \\
\text { Emirates }\end{array}$ \\
\hline Venezuela & 26.81 & 1.508 & $7.9 \%$ & (a) & $>3.72 *$ & $(37.39 \& 8.561)$ & $\begin{array}{l}\text { High to oil sands, Low to extra } \\
\text { high Sulfur Content }\end{array}$ & $\begin{array}{l}\text { Federal } \\
\text { Republic }\end{array}$ \\
\hline
\end{tabular}

*Assumption based on a R/P ratio equal to 100 years. (a): more than 100 years, (b): reflects a return to pre-Gulf crisis immigration of expatriates. 


\subsection{Panel data analysis}

To complement our time series analysis, we now implement panel cointegration tests by searching for a long-term relationship between the production of the various countries and the total OPEC production. We consider the seven tests proposed by Pedroni (1999, 2004). ${ }^{7}$ These tests are based on the null hypothesis of no cointegration. Among the 7 Pedroni's tests, 4 are based on the within dimension (panel cointegration tests) and 3 on the between dimension (group-mean panel cointegration tests). Group-mean panel cointegration statistics are more general in the sense that they allow for heterogeneous coefficients under the alternative hypothesis: under the alternative hypothesis, there exists a cointegration relationship, and this relationship is not necessarily the same for each country.

Results from Pedroni's tests are reported in Table 5. As it is frequently the case, these results are somewhat mixed. They can be summarized as follows. Considering first the group-mean panel cointegration tests, the null hypothesis of no cointegration is always rejected, meaning that a long-term relationship exists between the production series, whatever the panel and the sub-period considered. Turning now to the tests based on the within dimension, the results are less clear-cut. Indeed, if the homogeneity assumption of the cointegrating relationship between countries is retained, our findings show that the null of no cointegration is not rejected in the following cases: (i) the 1986.05-1993.02 sub-period for the three groups of countries, and (ii) the 1982.05-1986.04, 1986.05-1993.02 and 1993.02-2000.12 periods for the group of spenders. To sum up, these findings tend to show that OPEC acts as a cartel especially with the group of savers since there exists a long-term relationship between the production of countries belonging to this group and the total OPEC production. The influence of the OPEC seems to be weakened on the 1982.05-1993.02 sub-period since no cointegrating relationship exists on this sub-period, including the case of the savers' countries. This result is not surprising and illustrates the decreasing influence of the OPEC following the oil countershock.

\footnotetext{
${ }^{7}$ Panel unit root tests have been applied (see Table A4 in the appendix) and show that all production series are integrated of order 1, whether one considers the complete panel or the two sub-samples. This confirms the findings obtained in the time series framework.
} 
Table 5. Panel cointegration tests (p-values).

\begin{tabular}{|c|c|c|c|c|c|c|c|}
\hline & \multicolumn{4}{|c|}{ Panel cointegration tests } & \multicolumn{3}{|c|}{ Group-mean panel cointegration tests } \\
\hline & Panel v & Panel rho & Panel PP & Panel $A D F$ & $\begin{array}{c}\text { Group- } \\
\text { mean rho }\end{array}$ & $\begin{array}{c}\text { Group- } \\
\text { mean PP }\end{array}$ & $\begin{array}{c}\text { Group- } \\
\text { mean ADF }\end{array}$ \\
\hline \multicolumn{8}{|l|}{ All OPEC } \\
\hline $\begin{array}{l}1973.01- \\
1982.02\end{array}$ & 0.1086 & $0 * * *$ & $0.0001 * * *$ & $0 * * *$ & $0 * * *$ & $0 * * *$ & $0 * * *$ \\
\hline $\begin{array}{l}1982.03- \\
1986.04\end{array}$ & 0.1720 & $0.002 * * *$ & $0 * * *$ & $0 * * *$ & $0.0002 * * *$ & $0 * * *$ & $0 * * *$ \\
\hline $\begin{array}{l}1986.05- \\
1993.02\end{array}$ & 0.2974 & 0.2554 & 0.2700 & 0.3439 & $0 * * *$ & $0 * * *$ & $0 * * *$ \\
\hline $\begin{array}{l}1993.03- \\
2000.12\end{array}$ & $0.0275 * *$ & $0.0135 * *$ & $0.0745 *$ & 0.1166 & $0 * * *$ & $0 * * *$ & $0 * * *$ \\
\hline $\begin{array}{l}2001.01- \\
2009.07\end{array}$ & $0 * * *$ & $0 * * *$ & $0 * * *$ & $0 * * *$ & $0 * * *$ & $0 * * *$ & $0 * * *$ \\
\hline \multicolumn{8}{|l|}{ Savers } \\
\hline $\begin{array}{l}1973.01- \\
1982.02\end{array}$ & 0.3058 & $0 * * *$ & $0.0017 * * *$ & $0.0012 * * *$ & $0 * * *$ & $0 * * *$ & $0 * * *$ \\
\hline $\begin{array}{l}1982.03- \\
1986.04\end{array}$ & 0.1923 & $0.0105^{* *}$ & $0 * * *$ & $0 * * *$ & $0.0066^{* * * *}$ & $0.0002 * * *$ & $0.0002 * * *$ \\
\hline $\begin{array}{l}1986.05- \\
1993.02\end{array}$ & 0.2400 & 0.2045 & 0.2464 & 0.3342 & $0.0008 * * *$ & $0.0017 * * *$ & $0.0002 * * *$ \\
\hline $\begin{array}{l}1993.03- \\
2000.12\end{array}$ & 0.1025 & $0 * * *$ & $0.0010 * * *$ & $0.0012 * * *$ & $0 * * *$ & $0 * * *$ & $0.0001 * * *$ \\
\hline $\begin{array}{l}2001.01- \\
2009.07\end{array}$ & $0 * * *$ & $0 * * *$ & $0.0002 * * *$ & $0 * * *$ & $0.0347 * *$ & $0.0958 *$ & $0.0022 * * *$ \\
\hline \multicolumn{8}{|l|}{ Spenders } \\
\hline $\begin{array}{l}1973.01- \\
1982.02\end{array}$ & $0 * * *$ & $0 * * *$ & $0.0053 * * *$ & $0.0089 * * *$ & $0.0020 * * *$ & $0.0043 * * *$ & $0.0049 * * *$ \\
\hline $\begin{array}{l}1982.03- \\
1986.04\end{array}$ & 0.3919 & 0.1489 & 0.1329 & $0.0046 * * *$ & $0.0083 * * *$ & $0.0069 * * *$ & $0.0003 * * *$ \\
\hline $\begin{array}{l}1986.05- \\
1993.02\end{array}$ & 0.3942 & 0.3983 & 0.3981 & 0.3980 & $0.0051 * * *$ & $0.0057 * * *$ & $0.0041 * * *$ \\
\hline $\begin{array}{l}1993.03- \\
2000.12\end{array}$ & 0.1338 & 0.3505 & 0.3976 & 0.3915 & $0.0146 * *$ & $0.0933^{*}$ & 0.1084 \\
\hline $\begin{array}{l}2001.01- \\
2009.07\end{array}$ & $0 * * *$ & $0 * * *$ & $0 * * *$ & $0 * * *$ & $0.0001 * * *$ & $0.0007 * * *$ & $0.0009 * * *$ \\
\hline
\end{tabular}

In order to investigate the direction of the link between production and price series, we now proceed to Granger-type causality tests. Results are reported in Table 6. When a causal link exists, it generally runs from price to production. Indeed, a causality running from production to price is observed only in the following cases: (i) on the 1986.05-1993.02 sub-period for the complete panel and the group of savers, (ii) on the 1982.03-1986.04 sub-period for the group of spenders, and (iii) on the whole period for the savers' countries. These results tend to confirm the findings of the cointegration tests since they put forward a higher influence of the OPEC on the group of savers. They also highlight the growing role of the OPEC during the 
1982.03-1986.04 sub-period-with a causality running from production to price in the group of spenders-corresponding to the introduction of quotas and the development of the spot market.

Table 6. Granger causality tests (p-values).

\begin{tabular}{|c|c|c|c|c|c|}
\hline & $\begin{array}{c}1973.01- \\
1982.02\end{array}$ & $\begin{array}{c}1982.03- \\
1986.04\end{array}$ & $\begin{array}{l}1986.05- \\
1993.02\end{array}$ & $\begin{array}{l}1993.03- \\
2000.12\end{array}$ & $\begin{array}{c}2001.07- \\
2009.07\end{array}$ \\
\hline \multicolumn{6}{|l|}{ All OPEC } \\
\hline Price-Prod & 0.1869 & $0.0040 * * *$ & $0.0083 * * *$ & $0.0242 * *$ & $0.0875^{*}$ \\
\hline Prod-Price & 0.5534 & 0.1149 & $0.0157 * *$ & 0.6285 & 0.8423 \\
\hline \multicolumn{6}{|l|}{ Savers } \\
\hline Price-Prod & 0.2169 & $0.0006^{* * * *}$ & 0.1157 & $0.0418 * *$ & $0.0001 * * *$ \\
\hline Prod-Price & 0.2189 & 0.1959 & $0.0966^{*}$ & 0.5502 & 0.1057 \\
\hline \multicolumn{6}{|l|}{ Spenders } \\
\hline Price-Prod & 0.4736 & 0.1130 & $0.0332 * *$ & $0.0822 *$ & 0.1979 \\
\hline Prod-Price & 0.9175 & $0.0409 * *$ & 0.2196 & 0.7902 & 0.6738 \\
\hline
\end{tabular}

\section{Conclusion}

In this paper, we analyze the evolution of the production behavior of countries belonging to the OPEC, as well as four non-member countries that are considered as key players in the oil market (Mexico, Norway, Russia, and the UK). More specifically, we aim at determining if OPEC acts as a cartel. To this end, we rely on time series and panel cointegration and causality tests to investigate whether production decisions of the different countries are coordinated and if they have an influence on oil prices.

Our findings shows that the influence of OPEC has evolved through time, following the changes in the oil pricing system registered on the market. In particular, investigating the OPEC behavior on various sub-periods, we find that, while OPEC's influence was strong in the period that just follows the oil counter-shock, it acts as a price taker for the majority of the considered sub-periods since 1973. Finally, by splitting OPEC into two groups, the savers and spenders, we show that OPEC may be viewed as a divided organization in the sense that it acts as a cartel mainly with a subgroup of its members. 


\section{References}

Adelman, M.A. (1982), "OPEC as a Cartel”, in Griffin, G.M. and Teece, D.J. (eds), OPEC Behavior and World Oil Prices (London: George Allen \& Unwin).

Alhajji, A.F. and Huettner, D. (2000), “OPEC and other commodity cartels: a comparison", Energy Policy 28, 1151-1164.

Aperjis, D. (1982), The Oil Market in the 1980s, OPEC Oil Policy and Economic Development, Cambridge, MA: Ballinger Publishing Company.

BP (2009), Statistical Review of World Energy, June.

Dahl, C., Yücel, M. (1989), "Dynamic Modeling and testing of OPEC Behavior”, Research Paper 8917, Federal Reserve Bank of Dallas.

Engle, R.F. and Granger, C.W.J. (1987), "Cointegration and Error Correction: Representation, Estimation and Testing", Econometrica 55, 251-276.

Fattouh, B. (2006), "The origins and evolution of the current international oil pricing system: A critical assessment", in R. Mabro (ed.) Oil in the Twenty-First Century: Issues, Challenges, and Opportunities, Oxford: Oxford University Press.

Griffin, J.M. (1985), "OPEC Behavior: A Test of Alternative Hypotheses", American Economic Review 75(5), 954-963.

Griffin, G.M. and Teece, D.J. (1982), OPEC Behavior and World Oil Prices, George Allen \& Unwin (Publishers) Ltd, UK.

Gülen, S.G. (1996), "Is OPEC a Cartel? Evidence from Cointegration and Causality Tests", The Energy Journal 17(2), 43-57.

Hadri, K. (2000), "Testing for unit roots in heterogeneous panel data”, Econometrics Journal 3, 148-161.

Hnyilicza, E. and Pindyck, R. S. (1976), "Pricing Policies for a Two-part Exhaustible Resource Cartel, the Case of OPEC”, European Economic Review 8, 139-154.

Im, K.S., Pesaran, M.H. and Shin, Y. (2003), "Testing for unit roots in heterogeneous panels", Journal of Econometrics 115, 53-74.

Johany, A. D. (1980), The Myth of the OPEC Cartel, the Role of Saudi Arabia, New York: John Wiley and sons.

Loderer, C. (1985), “A Test of the OPEC Cartel Hypothesis: 1974-1983”, Journal of Finance 40(3), 991-1006.

MacAvoy, P. (1982), Crude Oil Prices as Determined by OPEC and Market Fundamentals, Cambridge, MA: Ballinger Publishing Company.

Maddala, G. and Wu, S. (1999), "A comparative study of unit root tests and a new simple test", Oxford Bulletin of Economics and Statistics 61, 631-652. 
Pedroni, P. (1999), "Critical values for cointegration tests in heterogeneous panels with multiple regressors", Oxford Bulletin of Economics and Statistics S1, 61, 653-670.

Pedroni, P. (2004), "Panel cointegration. Asymptotic and finite sample properties of pooled time series tests with an application to the PPP hypothesis", Econometric Theory 20, 597-625.

Teece, D. (1982), "OPEC Behaviour: An alternative view", in Griffin, G.M. and Teece, D.J. (eds), OPEC Behavior and World Oil Prices (London: George Allen \& Unwin).

Yergin, D. (2008), The Prize. The Quest for Oil, Money and Power, New York, Simon \& Schuster.

Zivot, E. and Andrews, D. (1992), "Further evidence of great crash, the oil price shock and unit root hypothesis", Journal of Business and Economic Statistics 10, 251-270. 
Table A1. Results of the Zivot and Andrews test.

\begin{tabular}{|c|c|c|c|c|c|}
\hline & $\begin{array}{c}1973.01- \\
1982.02\end{array}$ & $\begin{array}{l}1982.02- \\
1986.04\end{array}$ & $\begin{array}{c}1986.05- \\
1993.02\end{array}$ & $\begin{array}{l}1993.03- \\
2000.12\end{array}$ & $\begin{array}{r}2001.01- \\
2009.07\end{array}$ \\
\hline Algeria & $\mathrm{I}(1)$ & $\mathrm{I}(1)$ & $\mathrm{I}(1)$ & $\mathrm{I}(1)$ & $\mathrm{I}(2)$ \\
\hline Algeria2 & $\mathrm{I}(1)$ & $\mathrm{I}(1)$ & $\mathrm{I}(1)$ & $\mathrm{I}(1)$ & $\mathrm{I}(1)$ \\
\hline Indonesia & $\mathrm{I}(1)$ & $\mathrm{I}(1)$ & $\mathrm{I}(1)$ & $\mathrm{I}(1)$ & $\mathrm{I}(1)$ \\
\hline Indonesia2 & $\mathrm{I}(1)$ & $\mathrm{I}(1)$ & $\mathrm{I}(1)$ & $\mathrm{I}(1)$ & $\mathrm{I}(1)$ \\
\hline Iran & $\mathrm{I}(1)$ & $\mathrm{I}(0)$ & $\mathrm{I}(0)$ & $\mathrm{I}(0)$ & $\mathrm{I}(1)$ \\
\hline Iran2 & $\mathrm{I}(1)$ & $\mathrm{I}(1)$ & $\mathrm{I}(1)$ & $\mathrm{I}(1)$ & $\mathrm{I}(1)$ \\
\hline Iraq & $\mathrm{I}(0)$ & $\mathrm{I}(1)$ & $\mathrm{I}(0)$ & $\mathrm{I}(1)$ & $\mathrm{I}(1)$ \\
\hline Iraq2 & $\mathrm{I}(1)$ & $\mathrm{I}(1)$ & $\mathrm{I}(1)$ & $\mathrm{I}(1)$ & $\mathrm{I}(1)$ \\
\hline Kuwait & $\mathrm{I}(1)$ & $\mathrm{I}(1)$ & $\mathrm{I}(0)$ & $\mathrm{I}(0)$ & $\mathrm{I}(1)$ \\
\hline Kuwait2 & $\mathrm{I}(1)$ & $\mathrm{I}(1)$ & $\mathrm{I}(1)$ & $\mathrm{I}(1)$ & $\mathrm{I}(1)$ \\
\hline Libya & $\mathrm{I}(1)$ & $\mathrm{I}(0)$ & $\mathrm{I}(1)$ & $\mathrm{I}(1)$ & $\mathrm{I}(1)$ \\
\hline Libya2 & $\mathrm{I}(1)$ & $\mathrm{I}(1)$ & $\mathrm{I}(1)$ & $\mathrm{I}(1)$ & $\mathrm{I}(1)$ \\
\hline Nigeria & $\mathrm{I}(1)$ & $\mathrm{I}(0)$ & $\mathrm{I}(1)$ & $\mathrm{I}(1)$ & $\mathrm{I}(1)$ \\
\hline Nigeria2 & $\mathrm{I}(1)$ & $\mathrm{I}(1)$ & $\mathrm{I}(1)$ & $\mathrm{I}(1)$ & $\mathrm{I}(1)$ \\
\hline Qatar & $\mathrm{I}(1)$ & $\mathrm{I}(1)$ & $\mathrm{I}(1)$ & $\mathrm{I}(1)$ & $\mathrm{I}(1)$ \\
\hline Qatar2 & $\mathrm{I}(1)$ & $\mathrm{I}(1)$ & $\mathrm{I}(1)$ & $\mathrm{I}(1)$ & $\mathrm{I}(1)$ \\
\hline Saudi Arabia & $\mathrm{I}(1)$ & $\mathrm{I}(2)$ & $\mathrm{I}(1)$ & $\mathrm{I}(1)$ & $\mathrm{I}(1)$ \\
\hline Saudi Arabia2 & $\mathrm{I}(1)$ & $\mathrm{I}(0)$ & $\mathrm{I}(0)$ & $\mathrm{I}(1)$ & $\mathrm{I}(1)$ \\
\hline U.A.E. & $\mathrm{I}(0)$ & $\mathrm{I}(2)$ & $\mathrm{I}(0)$ & $\mathrm{I}(1)$ & $\mathrm{I}(1)$ \\
\hline U.A.E. 2 & $\mathrm{I}(1)$ & $\mathrm{I}(1)$ & $\mathrm{I}(1)$ & $\mathrm{I}(1)$ & $\mathrm{I}(1)$ \\
\hline Venezuela & $\mathrm{I}(1)$ & $\mathrm{I}(1)$ & $\mathrm{I}(2)$ & $\mathrm{I}(2)$ & $\mathrm{I}(1)$ \\
\hline Venezuela2 & $\mathrm{I}(1)$ & $\mathrm{I}(1)$ & $\mathrm{I}(0)$ & $\mathrm{I}(1)$ & $\mathrm{I}(1)$ \\
\hline OPEC & $\mathrm{I}(1)$ & $\mathrm{I}(1)$ & $\mathrm{I}(1)$ & $\mathrm{I}(1)$ & $\mathrm{I}(1)$ \\
\hline Mexico & - & $\mathrm{I}(1)$ & $\mathrm{I}(0)$ & $\mathrm{I}(1)$ & $\mathrm{I}(1)$ \\
\hline Norway & - & $\mathrm{I}(2)$ & $\mathrm{I}(0)$ & $\mathrm{I}(1)$ & $\mathrm{I}(1)$ \\
\hline U.K. & - & $\mathrm{I}(1)$ & $\mathrm{I}(1)$ & $\mathrm{I}(1)$ & $\mathrm{I}(1)$ \\
\hline Russia & - & - & - & $\mathrm{I}(1)$ & $\mathrm{I}(1)$ \\
\hline
\end{tabular}

- : data unavailable

$\mathrm{I}(0)$ (resp. I(1), I(2)) : series are integrated of order 0 (resp. 1, 2). 
Table A2. Results of the Engle-Granger cointegration test.

$\begin{array}{lllll}1973.01-1982.02 & 1982.03-1986.04 & 1986.05-1993.01 & 1993.02-2000.12 & 2001.01-2009.07\end{array}$

\begin{tabular}{|c|c|c|c|c|c|}
\hline Algeria & $-3.661401 * *$ & $-4.635594 * * *$ & -3.02 & -1.80 & \\
\hline Indonesia & & $-3.947677 * *$ & $-3.42 * *$ & -2.067579 & -2.613474 \\
\hline Iran & & & & & $-5.205437 * * *$ \\
\hline Iraq & & -1.479097 & & & \\
\hline Kuwait & $-4.851446 * * *$ & -2.351365 & & & $-3.09 *$ \\
\hline Libya & & & $-3.57 * *$ & -2.48 & -1.699279 \\
\hline Nigeria & $-3.652785 * *$ & & $-4.59 * * *$ & $-4.700496 * * *$ & $-3.512724 * *$ \\
\hline Qatar & $-6.498419 * * *$ & -3.12 & $-5.79 * * *$ & $-5.146397 * * *$ & $-3.717335^{* *}$ \\
\hline Saudi Arabia & & & & $-3.730816 * *$ & $-3.114570 *$ \\
\hline U.A.E. & & & & $-6.38 * * *$ & $-3.071073^{*}$ \\
\hline
\end{tabular}

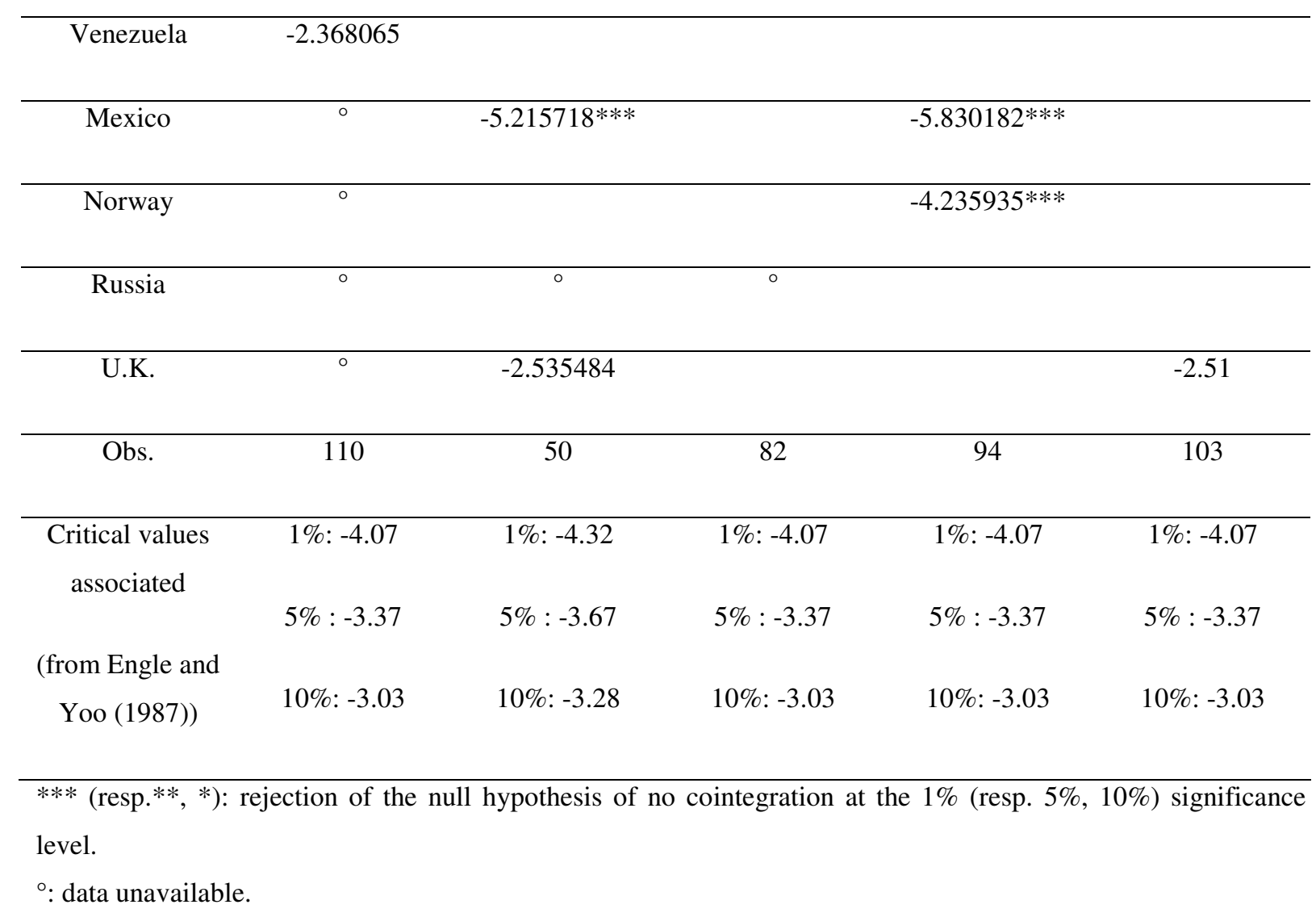


Table A3. Results of the Granger causality test.

\begin{tabular}{|c|c|c|c|c|c|c|c|c|c|c|}
\hline & \multicolumn{2}{|c|}{ 1973.01-1982.02 } & \multicolumn{2}{|c|}{ 1982.03-1986.04 } & \multicolumn{2}{|c|}{ 1986.05-1993.02 } & \multicolumn{2}{|c|}{$1993.03-2000.12$} & \multicolumn{2}{|c|}{ 2001.01-2009.07 } \\
\hline & $\begin{array}{l}\text { Price- } \\
\text { Prod }\end{array}$ & $\begin{array}{l}\text { Prod- } \\
\text { Price }\end{array}$ & $\begin{array}{l}\text { Price- } \\
\text { Prod }\end{array}$ & $\begin{array}{l}\text { Prod- } \\
\text { Price }\end{array}$ & $\begin{array}{l}\text { Price- } \\
\text { Prod }\end{array}$ & Prod-Price & $\begin{array}{l}\text { Price- } \\
\text { Prod }\end{array}$ & Prod-Price & Price-Prod & $\begin{array}{l}\text { Prod- } \\
\text { Price }\end{array}$ \\
\hline Algeria & & & 0.1394 & $0.0169^{* *}$ & & $0.0057 * * *$ & 0.6418 & 0.1698 & - & - \\
\hline Indonesia & 0.9449 & & 0.4685 & 0.5656 & 0.1425 & 0.9644 & 0.5177 & 0.5177 & 0.1397 & 0.7732 \\
\hline Iran & & & - & - & - & - & - & & $0.0005 * * *$ & 0.2494 \\
\hline Iraq & - & - & 0.1902 & $0.0630 *$ & - & - & & 0.8693 & & 0.4157 \\
\hline Kuwait & 0.5418 & & 0.6882 & 0.9961 & - & - & - & - & $0.0006 * * *$ & 0.4112 \\
\hline Libya & $0.0066^{* * * *}$ & & - & - & 0.9712 & $0.0083 * * *$ & & 0.3839 & $0 * * *$ & 0.9666 \\
\hline Nigeria & & & - & - & 0.7185 & $0.0008 * * *$ & 0.3887 & 0.5623 & 0.8383 & 0.8253 \\
\hline Qatar & 0.7250 & & $0.0143 * *$ & 0.4219 & 0.3938 & $0.0052 * * *$ & & 0.9589 & & 0.5803 \\
\hline Saudi Arabia & 0.1260 & & - & - & $0.0003 * * *$ & $0.0659 *$ & 0.4183 & 0.6188 & $0 * * *$ & 0.8805 \\
\hline U.A.E. & - & - & - & - & - & - & $\begin{array}{l}0.0013 * \\
* *\end{array}$ & $0.0014 * * *$ & $0.0001 * * *$ & 0.6882 \\
\hline Venezuela & 0.5976 & & $0.0004 * * *$ & 0.4293 & - & - & - & - & & $0.0676^{*}$ \\
\hline OPEC & 0.2359 & & $0.0789 *$ & 0.6855 & 0.2506 & 0.0797* & $\begin{array}{l}0.0092 * \\
* *\end{array}$ & 0.1525 & $0 * * *$ & 0.6339 \\
\hline Mexico & $\circ$ & $\circ$ & $0.0054 * * *$ & 0.9346 & - & - & $\begin{array}{l}0.0001 * \\
* *\end{array}$ & 0.5911 & 0.4669 & 0.7461 \\
\hline Norway & $\circ$ & $\circ$ & - & - & - & - & 0.7146 & 0.2452 & 0.6690 & 0.1007 \\
\hline U.K. & $\circ$ & $\circ$ & 0.6079 & 0.4237 & 0.4410 & 0.7902 & 0.3488 & 0.3488 & 0.7344 & 0.4619 \\
\hline Russia & $\circ$ & $\circ$ & $\circ$ & $\circ$ & $\circ$ & $\circ$ & 0.7868 & 0.6458 & $0.0052 * * *$ & 0.4406 \\
\hline
\end{tabular}

Price-prod: null of no causality from price to production, prod-price: null of no causality from production to price.

-: different orders of integration.

${ }^{\circ}$ : data unavailable. 
Table A4. Panel unit root tests (p-values).

\begin{tabular}{lccc}
\hline & IPS & MW & Hadri \\
\hline All OPEC & 0.3064 & 0.4652 & $0^{* * *}$ \\
Savers & 0.3238 & 0.3880 & $0^{* * *}$ \\
Spenders & 0.1321 & 0.5115 & $0^{* * *}$ \\
\hline This table reports the p-values of the following panel unit root tests: Im, Pesaran and Shin (IPS, 2003), Maddala \\
and Wu (1999, MW) and Hadri (2000). The IPS and MW tests consider the unit root as the null hypothesis, \\
while the Hadri (2000) test is based on the null of no unit root. \\
***: rejection of the null hypothesis at the 1\% significance level.
\end{tabular}




\section{The "Cahiers de l'Économie" Series}

The "Cahiers de l'économie" Series of occasional papers was launched in 1990 with the aim to enable scholars, researchers and practitioners to share important ideas with a broad audience of stakeholders including, academics, government departments, regulators, policy organisations and energy companies.

All these papers are available upon request at IFP School. All the papers issued after 2004 can be downloaded at: www.ifpen.fr

The list of issued occasional papers includes:

\section{\# 1. D. PERRUCHET, J.-P. CUEILLE}

Compagnies pétrolières internationales : intégration verticale et niveau de risque. Novembre 1990

\section{\# 2. C. BARRET, P. CHOLLET}

Canadian gas exports: modeling a market in disequilibrium.

Juin 1990

\section{\# 3. J.-P. FAVENNEC, V. PREVOT}

Raffinage et environnement.

Janvier 1991

\section{\# 4. D. BABUSIAUX}

Note sur le choix des investissements en présence de rationnement du capital. Janvier 1991

\section{\# 5. J.-L. KARNIK}

Les résultats financiers des sociétés de raffinage distribution en France 1978-89.

Mars 1991

\section{\# 6. I. CADORET, P. RENOU}

Élasticités et substitutions énergétiques : difficultés méthodologiques.

Avril 1991

\section{\# 7. I. CADORET, J.-L. KARNIK}

Modélisation de la demande de gaz naturel dans le secteur domestique : France, Italie, Royaume-Uni 1978-1989.

Juillet 1991

\section{\# 8. J.-M. BREUIL}

Émissions de SO2 dans l'industrie française : une approche technico-économique. Septembre 1991

\section{\# 9. A. FAUVEAU, P. CHOLLET, F. LANTZ}

Changements structurels dans un modèle économétrique de demande de carburant. Octobre 1991

\section{\# 10. P. RENOU}

Modélisation des substitutions énergétiques dans les pays de I'OCDE.

Décembre 1991

\section{\# 11. E. DELAFOSSE}

Marchés gaziers du Sud-Est asiatique : évolutions et enseignements.

Juin 1992

\section{\# 12. F. LANTZ, C. IOANNIDIS}

Analysis of the French gasoline market since the deregulation of prices.

Juillet 1992
\# 13. K. FAID

Analysis of the American oil futures market. Décembre 1992

\section{\# 14. S. NACHET}

La réglementation internationale pour la prévention et I'indemnisation des pollutions maritimes par les hydrocarbures.

Mars 1993

\# 15. J.-L. KARNIK, R. BAKER, D. PERRUCHET Les compagnies pétrolières : 1973-1993, vingt ans après.

Juillet 1993

\section{\# 16. N. ALBA-SAUNAL}

Environnement et élasticités de substitution dans I'industrie ; méthodes et interrogations pour l'avenir. Septembre 1993

\section{\# 17. E. DELAFOSSE}

Pays en développement et enjeux gaziers : prendre en compte les contraintes d'accès aux ressources locales. Octobre 1993

\section{\# 18. J.P. FAVENNEC, D. BABUSIAUX*}

L'industrie du raffinage dans le Golfe arabe, en Asie et en Europe : comparaison et interdépendance. Octobre 1993

\section{\# 19. S. FURLAN}

L'apport de la théorie économique à la définition d'externalité.

Juin 1994

\section{\# 20. M. CADREN}

Analyse économétrique de l'intégration européenne des produits pétroliers : le marché du diesel en Allemagne et en France.

Novembre 1994

\section{\# 21. J.L. KARNIK, J. MASSERON*}

L'impact du progrès technique sur l'industrie du pétrole. Janvier 1995

\section{\# 22. J.P. FAVENNEC, D. BABUSIAUX}

L'avenir de l'industrie du raffinage. Janvier 1995

\section{\# 23. D. BABUSIAUX, S. YAFIL*}

Relations entre taux de rentabilité interne et taux de rendement comptable.

Mai 1995

\section{\# 24. D. BABUSIAUX, J. JAYLET* ${ }^{\star}$}

Calculs de rentabilité et mode de financement des investissements, vers une nouvelle méthode? Juin 1996 


\section{\# 25. J.P. CUEILLE, J. MASSERON*}

Coûts de production des énergies fossiles : situation actuelle et perspectives.

Juillet 1996

\section{\# 26. J.P. CUEILLE, E. JOURDAIN}

Réductions des externalités : impacts du progrès technique et de l'amélioration de l'efficacité

énergétique.

Janvier 1997

\section{\# 27. J.P. CUEILLE, E. DOS SANTOS}

Approche évolutionniste de la compétitivité des activités amont de la filière pétrolière dans une perspective de long terme.

Février 1997

\section{\# 28. C. BAUDOUIN, J.P. FAVENNEC}

Marges et perspectives du raffinage. Avril 1997

\# 29. P. COUSSY, S. FURLAN, E. JOURDAIN, G. LANDRIEU, J.V. SPADARO, A. RABL

Tentative d'évaluation monétaire des coûts externes liés à la pollution automobile : difficultés méthodologiques et étude de cas.

Février 1998

\# 30. J.P. INDJEHAGOPIAN, F. LANTZ, V. SIMON

Dynamique des prix sur le marché des fiouls domestiques en Europe.

Octobre 1998

\section{\# 31. A. PIERRU, A. MAURO}

Actions et obligations : des options qui s'ignorent. Janvier 1999

\section{\# 32. V. LEPEZ, G. MANDONNET}

Problèmes de robustesse dans l'estimation des réserves ultimes de pétrole conventionnel. Mars 1999

\section{\# 33. J. P. FAVENNEC, P. COPINSCHI}

L'amont pétrolier en Afrique de l'Ouest, état des lieux Octobre 1999

\section{\# 34. D. BABUSIAUX}

Mondialisation et formes de concurrence sur les grands marchés de matières premières énergétiques : le pétrole.

Novembre 1999

\# 35. D. RILEY

The Euro

Février 2000

\section{\# 36. D. BABUSIAUX, A. PIERRU*}

Calculs de rentabilité et mode de financement des projets d'investissements : propositions méthodologiques.

Avril 2000 \& septembre 2000

\# 37. P. ALBA, O. RECH

Peut-on améliorer les prévisions énergétiques ? Mai 2000

\section{\# 38. J.P. FAVENNEC, D. BABUSIAUX}

Quel futur pour le prix du brut? Septembre 2000

\section{\# 39. S. JUAN, F. LANTZ}

La mise en œuvre des techniques de Bootstrap pour la prévision économétrique : application à l'industrie automobile Novembre 2000
\# 40. A. PIERRU, D. BABUSIAUX

Coût du capital et étude de rentabilité $d^{\prime}$ investissement : une formulation unique de I'ensemble des méthodes.

Novembre 2000

\section{\# 41. D. BABUSIAUX}

Les émissions de $\mathrm{CO} 2$ en raffinerie et leur affectation aux différents produits finis

Décembre 2000

\section{\# 42. D. BABUSIAUX}

Éléments pour l'analyse des évolutions des prix du brut.

Décembre 2000

\section{\# 43. P. COPINSCHI}

Stratégie des acteurs sur la scène pétrolière africaine (golfe de Guinée). Janvier 2001

\section{\# 44. V. LEPEZ}

Modélisation de la distribution de la taille des champs d'un système pétrolier, Log Normale ou Fractale ? Une approche unificatrice.

Janvier 2001

\section{\# 45. S. BARREAU}

Innovations et stratégie de croissance externe : Le cas des entreprises parapétrolières. Juin 2001

\section{\# 46. J. P. CUEILLE}

Les groupes pétroliers en 2000 : analyse de leur situation financière.* Septembre 2001

\section{\# 47. T. CAVATORTA}

La libéralisation du secteur électrique de I'Union européenne et son impact sur la nouvelle organisation électrique française Décembre 2001

\section{\# 48. P. ALBA, O. RECH}

Contribution à l'élaboration des scénarios énergétiques. Décembre 2001

\section{\# 49. A. PIERRU*}

Extension d'un théorème de dualité en programmation linéaire : Application à la décomposition de coûts marginaux de long terme. Avril 2002

\section{\# 50. T. CAVATORTA}

La seconde phase de libéralisation des marchés du gaz de l'Union européenne : enjeux et risques pour le secteur gazier français. Novembre 2002

\# 51. J.P. CUEILLE, L. DE CASTRO PINTO COUTHINO, J. F. DE MIGUEL RODRÍGUEZ*

Les principales compagnies pétrolières indépendantes américaines : caractéristiques et résultats récents. Novembre 2002

\section{\# 52. J.P. FAVENNEC}

Géopolitique du pétrole au début du XXI ${ }^{\mathrm{e}}$ siècle Janvier 2003

\section{\# 53. V. RODRIGUEZ-PADILLA avec la collaboration de} T. CAVATORTA et J.P. FAVENNEC, ${ }^{*}$

L'ouverture de l'exploration et de la production de gaz naturel au Mexique, libéralisme ou nationalisme Janvier 2003 


\section{\# 54. T. CAVATORTA, M. SCHENCKERY}

Les majors pétroliers vers le multi énergies : mythe ou réalité ?

Juin 2003

\section{\# 55. P.R. BAUQUIS}

What energy sources will power transport in the 21st century?

Janvier 2004

\section{\# 56. A. PIERRU, D. BABUSIAUX}

Evaluation de projets d'investissement par une firme multinationale : généralisation du concept de coût moyen pondéré du capital et conséquences sur la valeur de la firme.

Février 2004

\section{\# 57. N. BRET-ROUZAUT, M. THOM}

Technology Strategy in the Upstream Petroleum Supply Chain

Mars 2005

\section{\# 58. A. PIERRU}

Allocating the $\mathrm{CO}_{2}$ emissions of an oil refinery with Aumann-Shapley prices.

June 2005

\section{\# 59. F. LESCAROUX}

The Economic Consequences of Rising Oil Prices. Mai 2006

\section{\# 60. F. LESCAROUX, O. RECH}

L'origine des disparités de demande de carburant dans l'espace et le temps : l'effet de la saturation de l'équipement en automobiles sur l'élasticité revenu. Juin 2006

\section{\# 61. C. I. VASQUEZ JOSSE, A. NEUMANN}

Transatlantic Natural Gas Price and Oil Price Relationships - An Empirical Analysis. Septembre 2006

\section{\# 62. E. HACHE}

Une analyse de la stratégie des compagnies pétrolières internationales entre 1999 et 2004 Juillet 2006

\section{\# 63. F. BERNARD, A. PRIEUR}

Biofuel market and carbon modeling to evaluate French biofuel policy.

Octobre 2006

\# 64. E. HACHE

Que font les compagnies pétrolières internationales de leurs profits? Janvier 2007

\section{\# 65. A. PIERRU}

A note on the valuation of subsidized Loans Janvier 2007

\section{\# 66. D. BABUSIAUX, P. R. BAUQUIS}

Depletion of Petroleum Reserves and Oil Price trends Septembre 2007

\section{\# 67. F. LESCAROUX}

Car ownership in relation to income distribution and consumers's spending decisions. Novembre 2007

\section{\# 68. D. BABUSIAUX, A. PIERRU}

Short-run and long-run marginal costs of joint products in linear programming

Juin 2008

\section{\# 69. E. HACHE}

Commodities Markets: New paradigm or new fashion? Juillet 2008

\section{\# 70. D.BABUSIAUX, A. PIERRU}

Investment project valuation: A new equity perspective Février 2009

\section{\# 71. O. MASSOL, S. TCHUNG-MING}

Stratégies coopératives dans l'industrie du GNL :

l'argument de la rationalisation est-il fondé ? Février 2009

\section{\# 72. A. PIERRU, D.BABUSIAUX}

Valuation of investment projects by an international oil company: A new proof of a straightforward, rigorous method

Février 2009

\section{\# 73. E. SENTENAC CHEMIN}

Is the price effect on fuel consumption symmetric? Some evidence from an empirical study Avril 2009

\section{\# 74. E. HACHE}

OBAMA : Vers un green New Deal énergétique? Septembre 2009

\section{\# 75. O. MASSOL}

Cost function for the natural gas transmission industry: further considerations Septembre 2009

\# 76. F. LANTZ, E. SENTENAC CHEMIN

Analyse des tendances et des ruptures sur le marché automobile français. Modélisation du taux de diésélisation dans le parc Décembre 2010.

\# 77. B. CHÈZE, P. GASTINEAU, J. CHEVALLIER Forecasting air traffic and corresponding Jet-Fuel Demand until 2025 Décembre 2010 .

\section{\# 78. V. BREMOND, E. HACHE, V. MIGNON} Does OPEC still exist as a cartel? An empirical investigation Mars 2011.
* une version anglaise de cet article est disponible sur demande 